\title{
The Effect ofSilicon CarbideAddition into Fibreglass Reinforced Composites
}

\author{
Júlio César dos Santos", Rubens Bagni Torres, Luciano Machado Gomes Vieira, \\ Zélia Maria Velloso Miss agia, André Luis Chris toforo, Túlio Hallak Panzera
}

Department of Mechanical En gineering, Federal Univ ersity of SãoJoão delRei (UFSJ), São João del-Rei, 36.307-352, Brazil

\begin{abstract}
In today's modern world the composite materials have been widely used not only for aerospace/aeronautics, but also automotive, sports and construction industries. The flexural strength of laminated composites depends on the characteristics of dispersive and matrix phases, considering the presence of tensile and compressive loadings. For this reason, the addition of particles into the matrix phase has been investigated to enhance its stiffness and consequently the elastic modulus of the composite. This work investigates a glassfibre composite reinforced with silicon carbide particles. The following responses were evaluated: apparent density, water absorption, flexural strength, modulus of elasticity. The results were compared to those manufactured with no silicon carbide particles. It was observed that the silicon carbide particles provided the increase of the apparent density and flexural strength of the composites.
\end{abstract}

\section{Keywords Laminated Composites, Silicon Carbide, Fibre Glass, Hybrid Composites}

\section{Introduction}

The growing demand of composite materials has increased the attention to the theories of reinforced materials and advanced processes for their production.

Some industrial sectors, as the areas of missiles, rockets and aircraft, owned the restricted use of structural poly meric materials or advanced polymeric materials. Following decades of restriction, modern industries have expanded the use of these materials. The automotive, sports and construction industries [1,2] have experienced an increase of this technology every year due to their superior specific strength, lower density, higher corrosion resistance and high strength/modulus over conventional materials [3,4].

Replacement of metals by composites in commercial aircraft prime structures has been rapidly increasing to achieve further structural weight saving and reduce fuel consumption with a background of globally soaring oil prices[3].

Brazil has expanded their experience of innovation in the application of structural composites, especially in the aeronautics sector, using for external and internal planes/ helicopters (about $20 \%$ of the area of an aircraft) and a lesser extent for structure of rockets [3].

The dynamic flexural loadings in aircraft fuselage must be considered in the structural design. In th is case, the

* Corresponding author:

juliosantosjcs@hotmail.com(Júlio Cesar dos Santos)

Published online at http://journal.sapub.org/cmaterials

Copyright (C) 2012 Scientific \& Academic Publishing. All Rights Reserved composites must provide high stiffness and fatigueresistance[5, 6].

The modification of the mechanical behavior of poly mers by the addition of filler materials have shown a great importance in researches and has lately been a subject of considerable interest $[7,8]$.

In order to increase the flexural modulus of laminated composites, ceramic partic les have been added in the matrix phase to enhance the mechanical performance of laminated composites. Flexural strength of laminated composites can be improved with ceramic particles [9]. Silicon carbide (SiC) particles can improve thermal responses of poly mers [10] and some mechanical responses[11] of laminates.

This work investigates the physic-mechanical properties of hybrid polymeric composites reinforced with glass fib re and silicon carbide particles. The fatigue resistance and thermal properties will be the scope of future investigations.

\section{Materials and Methods}

\subsection{Epoxy Resin}

The epoxy resin was supplied by M/s. Alpha Resiqualy Company (São Paulo, Brazil). The addition of $66.66 \%$ of resin (RQ-0100RF) with $33.34 \%$ of hardening agent (RQ-0164RF PLUS) was mixed to obtain the matrix phase.

\subsection{Reinforcements Phases}

The glassfibre fabric of $240 \mathrm{~g} / \mathrm{m}^{2}$ was used in this experiment. The silicon carbide particles were supplied by M/s. Saint Gobain Company (Barbacena, Brazil) with 
particle size between mesh 200-325.

\subsection{Experimental Conditions}

The glass fibre reinforced composites were investigated by the use of matrix phase non-modified and modified with silicon carb ide partic les.

\subsection{Manufacture}

The specimens were fabricated by hand-lay-up process[12] according to the recommendations of Vison and Sierakowski[13] (Fig. 1).

For this research, the silicon carbide particles were sieved in mesh 200 - 325 US-Ty ler (the part icles retained on 325 US Tyler, were used).

By volume percent, the composite was shared in $30 \%$ of reinforced phase and $70 \%$ ofmatrix phase.

Three layers of glass fibre were cut into squares of $200 \mathrm{x}$ $150 \mathrm{~mm}$. Then, the mass of fibre was measured and the fibre volume $\left(\mathrm{V}_{\mathrm{f}}\right)$ of composite was calculated according eqn. 1:

$$
\mathrm{V}_{\mathrm{f}}=\mathrm{m}_{\mathrm{f}} / \rho_{\mathrm{f}}
$$

Where $\mathrm{m}_{\mathrm{f}}$ is the mass of fibre and $\rho_{\mathrm{f}}\left(2,5 \mathrm{~g} / \mathrm{cm}^{3}\right)$ is the density of fibre. According eqn. 2 , the volume of matrix $\left(\mathrm{V}_{\mathrm{m}}\right)$ was obtained:

$$
\mathrm{V}_{\mathrm{m}}=\left(\mathrm{V}_{\mathrm{f}} \times 70\right) / 30
$$

After, by density of matrix $\rho_{\mathrm{m}}\left(1,16 \mathrm{~g} / \mathrm{cm}^{3}\right)$, the matrix mass $\left(\mathrm{m}_{\mathrm{m}}\right)$ was obtained according eqn. 3 :

$$
\mathrm{m}_{\mathrm{m}}=\mathrm{V}_{\mathrm{m}} \times \rho_{\mathrm{m}}
$$

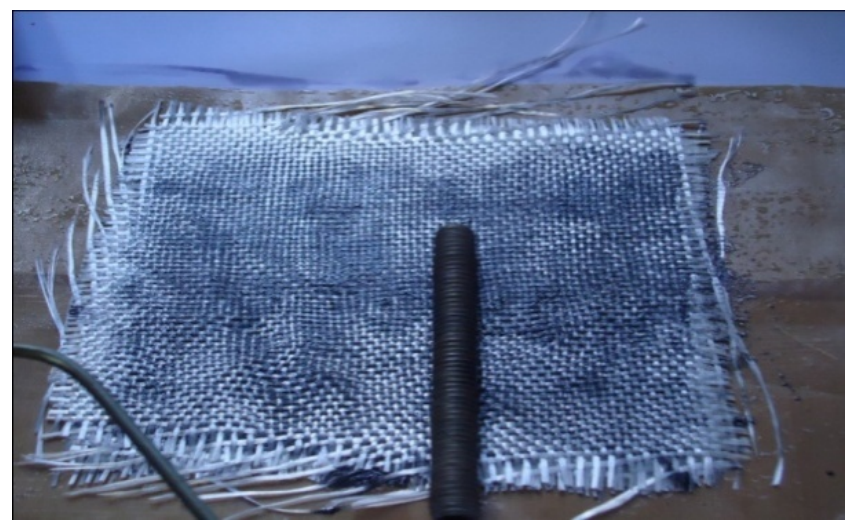

Figure 1. Hand lay-up method

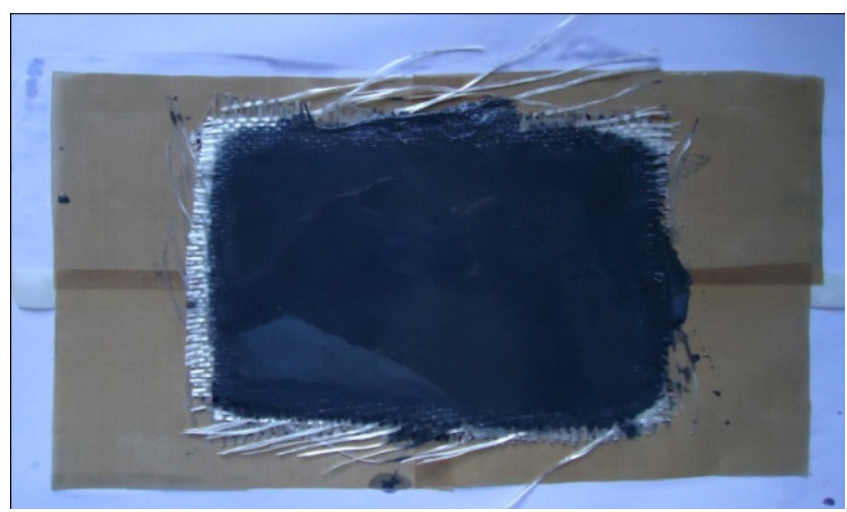

Figure 2. Silicon Carbide addition
The weight of particles mass was based in $20 \mathrm{wt} . \%$ (this amount was based in results of [14]). The silicon carbide particles were mixed into epoxy resin matrix, manually.

Later, the matrix reinforced with particles, was used for la minating of the three layers of glass fibre.

The Armalon ${ }^{\circledR}$ demoulding sheets were used at the bottom and upper surfaces in order to ensure a goodsurface fin ish,as shown in Fig. 2.

The samples were cured under room temperature, under 20 Newtons of uniaxial compressive forces, for 7 days.

\subsection{Methodol ogy}

\subsubsection{Relative density}

The apparent density was obtained according to ASTM SD792[15]. Test method a for testing solid plastics in water was used. By eqn. 4 was possible to calculate the relative density (rd) of sample:

$$
r d=a /(a+w-b)
$$

Where: a (apparent mass of specimen, without wire or sinker in air), b (apparent mass of completely immersed and of the wire partially immersed in liquid) and w (apparent mass of totally immersedand of partially immersed wire)[15].

\subsubsection{Water Absorption}

The water absorption was measured according to ASTM D570[16].

The specimens were immersed in saturated distilled water for 24 hours at $23^{\circ} \mathrm{C}$. The water absorption was calculated as follows:

$$
\%=\frac{\text { wet weight }- \text { cond.weight }}{\text { cond.weight }} \times 100
$$

Conditioned weight: is the mass of sample immersed in water.

The percentage of soluble matter lost during immersion, was determined by using the eqn.6.

$$
\%=\frac{\text { cond.weight }- \text { recond } . \text { weight }}{\text { cond.weight }} \times 100
$$

Recond. weight: mass of sample reconditioned in water after removal of there.

The percentage of water absorption was calculated dividing eqn 1 by eqn. 2 .

\subsubsection{Flexural Stress}

The samples were prepared according to ASTM D790[17], based on the recommendations of materials less than $1.6 \mathrm{~mm}$ in thickness.

The flexural strength was calculated by Eqn. 7 .

$$
\sigma_{f}=3 P L / 2 b d^{2}
$$

Where $\mathrm{P}$ is the load at a given point of load-deflection curve, $\mathrm{L}(25,4 \mathrm{~mm})$ is the support span, $\mathrm{b}(12,7 \mathrm{~mm})$ is the width and $d$ (mean of 1,28 ) is the depth of beam tested. 


\subsubsection{Modulus of Elasticity}

The modulus was obtained by the tangent modulus of elasticity in the ASTM D790 as follows:

$$
\mathrm{E}_{\mathrm{B}}=\left(\mathrm{L}^{3} \mathrm{~m}\right) /\left(4 \mathrm{bd}^{3}\right)
$$

Where $\mathrm{L}(25,4 \mathrm{~mm})$ is the support span, $\mathrm{b}(12,7 \mathrm{~mm})$ is the width of beam tested, $d$ (mean of 1,28 mm) is the depth of beam tested and $\mathrm{m}$ (calculated by graphic) is the slope of the tangent modulus (obtained by $50 \%$ deflection relative of the maximum flexu ral strength force).

\section{Results}

The comparisons between the results were carried out based on the Hypothesis Test for Difference of Means with Unknown Variances[18]. This analysis is able to verify whether the factor significant affects the response variables. The statistical analysis was performed for the flexural strength and modulus of elasticity responses. The other responses were analyzed based on the average and standard deviation of the experimental results.

Table 1 shows the means and standard deviations for each response variable.

Table 1. Means and standard deviations

\begin{tabular}{ccccc}
\hline \multirow{2}{*}{$\begin{array}{c}\text { Variable } \\
\text { Response }\end{array}$} & \multicolumn{2}{c}{ Without Particles } & \multicolumn{2}{c}{ With part icles } \\
\cline { 2 - 5 } $\begin{array}{c}\text { Mean } \\
\begin{array}{c}\text { Relative } \\
\text { density }\end{array}\end{array}$ & 1.56 & 0.096 & 1.63 & 0.005 \\
$\begin{array}{c}\text { Water } \\
\text { absorption }\end{array}$ & 5.83 & 0.056 & 2.69 & 0.008 \\
$\begin{array}{c}\text { Flexural stress } \\
\text { Modulus }\end{array}$ & 50.86 & 5.27 & 73.0806 & 9.63 \\
Elasticity & 6.65 & 0.77 & 6.63 & 0.44 \\
\hline
\end{tabular}

Table 2 gives the amounts for the hypothesis test for two averages. The confidence of $95 \%$ was set, wh ich corresponds to an $\alpha=$ level of $5 \%$.

Table 2. Test: Hypothesis test

\begin{tabular}{ccccc}
\hline V. R. & Hyp. & $\mathrm{t}_{\text {calc }}$ & $\mathrm{t}_{\text {tab }}$ & Concl. \\
\hline $\begin{array}{c}\text { Relative } \\
\text { Density }\end{array}$ & $\begin{array}{l}\mathrm{H}_{0}: \mu_{1}=\mu_{2} \\
\mathrm{H}_{0}: \mu_{1}>\mu_{2}\end{array}$ & 6,52 & 1,81 & Reject $\mathrm{H}_{0}$ \\
$\begin{array}{c}\text { Flexural } \\
\text { strength }\end{array}$ & $\begin{array}{l}\mathrm{H}_{0}: \mu_{1}=\mu_{2} \\
\mathrm{H}_{0}: \mu_{1}>\mu_{2}\end{array}$ & 4,52 & 1,81 & Reject $\mathrm{H}_{0}$ \\
$\begin{array}{l}\text { Flexural } \\
\text { modulus }\end{array}$ & $\mathrm{H}_{0}: \mu_{1}=\mu_{2}$ & 0,048 & 1,81 & Accept $\mathrm{H}_{0}$ \\
\hline
\end{tabular}

The comparison was performed between two means based on the $t$-student distribution, calculating the value of the " $t$ calculed" and comparing with "t tabulated". When the value of " $t$ calcu lated" is outside the region of acceptance covered by the "t tabulated data", then the initial hypothesis $\left(\mathrm{H}_{0}\right)$ is rejected[18].

\subsection{Relative Density}

The apparent density values of the composites varied from 1.50 to $1.63 \mathrm{~g} / \mathrm{cm}^{3}$. Fig. 3 shows the density graph for both conditions. The addition of siliconcarbide particles leads to an increase of $4.15 \%$ in apparent density of the material. This behavior was expected due to the higher density of silicon carbide particles.

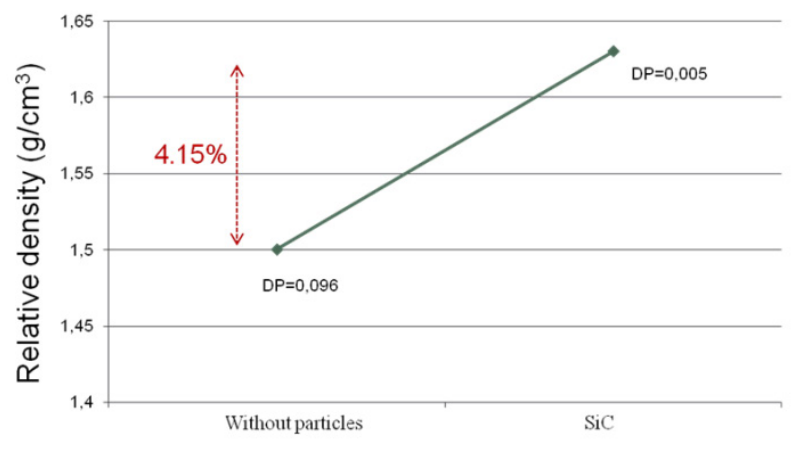

Figure 3. Graphic for Relative density

\subsection{Water Abs or ption}

The water absorption values of the composites decreased from $1.89 \%$ to $0,98 \%$. Fig. 4 shows the water absorption graph for both conditions.

The silicon carbide addition provided the reduction of $45.97 \%$ on the water absorption of the composites. Like the research of[11], one barrier properties appears, by the high loading of silicon carbide, covering the fibres. This layer of particles under the fibres, promoted a decrease of water absorption.

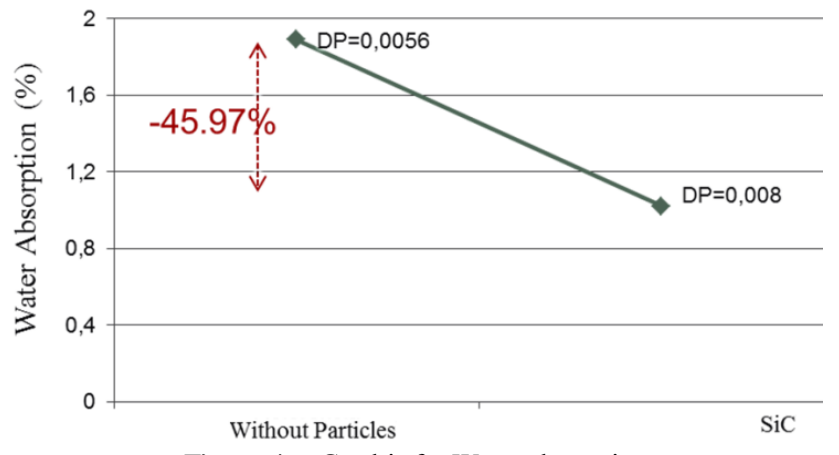

Figure 4. Graphic for Water absorption

\subsection{Fle xur al Strength}

The flexural strength data of the composites varied from 50,86 to $73,08 \mathrm{MPa}$.

Based on the hypothesis test, the flexural strength was significantly affected by the addition of silicon carbide particles, exh ibiting a rate of gro wingof $43,7 \%$. Fig. 5 shows the increase in flexural strength. 


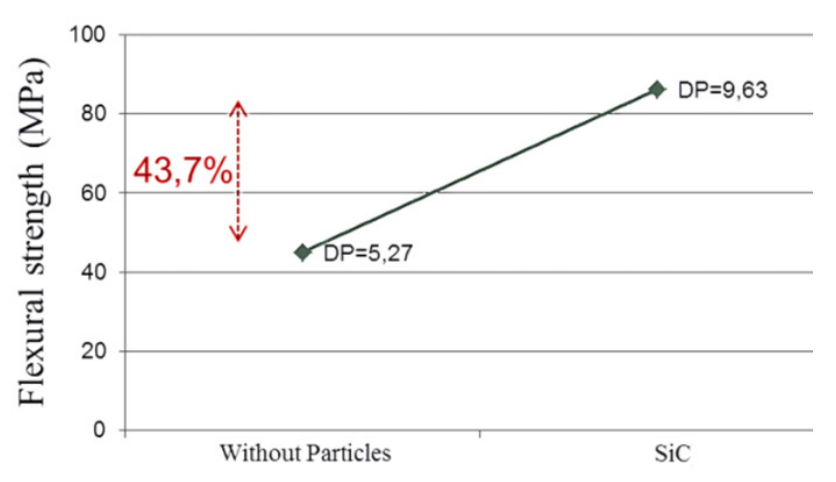

Figure 5. Graphic for Flexural Strength

The idea behind the increase is due the high silicon carb ide particles density, then the particles were decanted (fig. 3) under glass fibre, then, accord ing some arguments shown by[9] in his review, a fibre surface coating occurred. The particles promoted an increased in the roughening the fiber-matrix interface affecting the bonding strength between both, causing an increase in the shear stress transfer at the interface, collaborate to increase the flexural strength[9].

\subsection{Modul us of Elasticity}

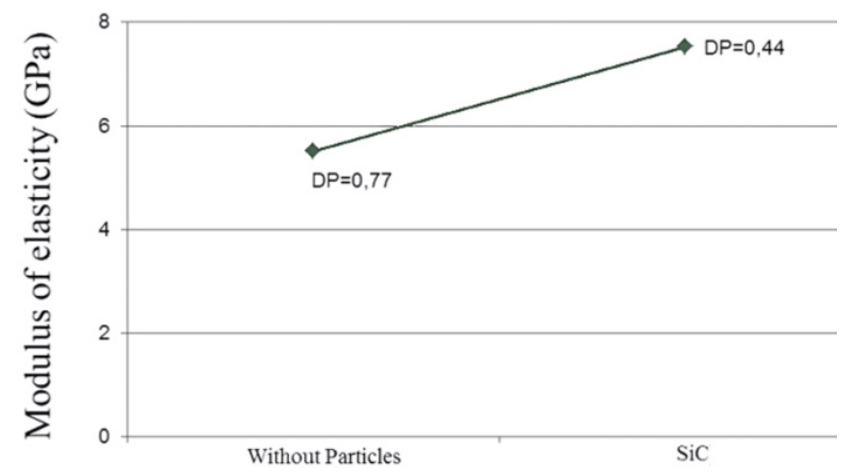

Figure 6. Increase of Modulus of Elasticity

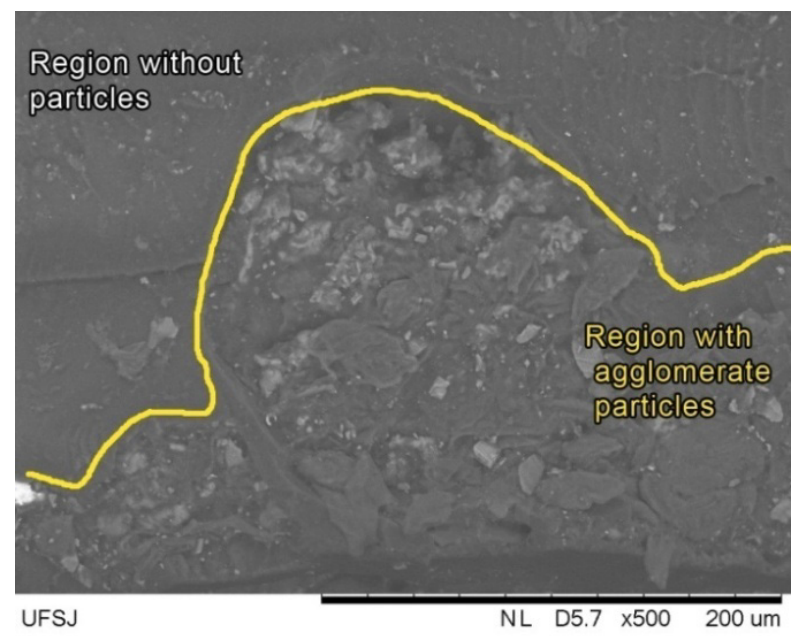

Figure 7. SEM - Agglomerates of silicon carbide particles in the inferior region of polymer

The modulus of elasticity varied from 6.65 to $6.63 \mathrm{GPa}$. The mean and standard deviation for each condition are shown in Table 1. Based on the Table 2, the two means are statistically the same (Table 2).

For this reason, it is concluded the particle addition did not affect this response. Fig. 6 shows the increase in modulus of elasticity.

The modulus did not affected by poor dispersion the particles into de epoxy matrix. Regions without particles in matrix phase can be observed (fig. 7). For improve the modulus, a good dipersion of particles, should be promoted.

\section{Conclusions}

The addition of micron silicon carbide particles provided the increase of apparent density and the reduction of water absorption of the composites. The addition of particles increased the flexural strength; however the modulus of elasticity was not significantly affected.

\section{REFERENCES}

[1] M. S. Issa, I.M. Metwally, S. M. Elzeiny. "Influence of fibers on flexural behavior and ductility of concrete beams reinforced with GFRP rebars", Engineering Structures, Volume 33, pp 1754-1763, 2011.

[2] P. J. D. Mendes, J. A.O. Barros, J. M. Sena-Cruz. M. Taheri. "Development of a pedestrian bridge with GFRP profiles and fiber reinforced self-compacting concrete deck", Composite Structures, Vol. 93, pp 2969-2982, 2011.

[3] M. C. Rezende. "O Uso de Compósitos Estruturais na Indústria Aeroespacial." Polímeros: Ciência e Tecnologia, vol $10, n^{\circ} 2,2000$.

[4] D. Qian, L. Bao, M. Takatera, K. Kemmochi, A. Yamanaka. "Fiber-reinforced polymer composite materials with high specific strength and excellent solid particle erosion resistance". Wear, Vol. 268, PP 637-642. 2010.

[5] R. M. Sullivan, P. L.N. Murthy, S. K. Mital, J. L. Palko, J. C. Cuneo, J. R. Koenig. "Development of Design Analysis Methods for Carbon Silicon Carbide Composite Structures." Journal of Composite Materials, vol. 41, $\mathrm{n}^{\circ}$. 10, 2007.

[6] B. Suresha, G. Chandramohan, N. M. Renukappa. "Influence of Silicon Carbide Filler on Mechanical and Dielectric Properties of Glass Fabric Reinforced Epoxy Composites."Journal of Applied Polymer Science, Vol. 111, pp 685-691. 2009.

[7] S. Basavarajappa, K.V. Arun, J. Paulo Davim. "Effect of Filler Materials on Dry Sliding Wear Behavior of Polymer MatrixComposites - A Taguchi Approach".Journal of Minerals \& Materials Characterization \& Engineering, Vol. 8, No.5, pp 379-391, 2009.

[8] V. Fiore, F. Alagna, G. Galtieri, C. Borsellino, G. Di Bella, A. Valenza. "Effect of curing time on the performances of hybrid/mixed joints." Composites Part B: Engineering, ISSN 1359-8368. 2012.

[9] Y. Cao, J. Cameron. "Flexural and Shear Properties of Silica Particle Modified Glass Fiber Reinforced Epoxy Composite." 
Journal of Reinforced Plastics and Composites.2006; 25; 347originally published online Aug 16, 2005.DOI: $10.1177 / 0731684405056450$.

[10] R. M. Rodgers, H. Mahfuz, V. K. Rangari, N. Chisholm, S. Jeelani. "Infusion od SiC Nanoparticles Into SC-15 Epoxy: Na Investigation of Thermal and Mechanical Response." Macromolecular Materials and Engineering. 2005, 290, 423-429. 2005.

[11] H. Alamri, I.M. Low. "Effect of water absorption on the mechanical properties of $\mathrm{n}-\mathrm{SiC}$ filled recy cled cellulose fibre reinforced epoxy eco-nanocomposites". Polymer Testing, Volume 31, Issue 6, PP 810-818, ISSN 0142-9418, 2012.

[12] E. Sevkat, M. Brahimi. "The bearing strength of pin loaded woven composites manufactured by vacuum assisted resin transfer moulding and hand lay-up techniques". Procedia Engineering, Volume 10, pp 153-158, 2011.

[13] J. R. Vison, R. L. Sierakowski. "The Behavior of Structures Composed of CompositeM aterials." 2 ed. Nem York: Kluwer Academic Publishers, pp 16-17, 2002.

[14] L. J. da Silva, T. H. Panzera, V. R. Velloso, A. L. Christoforo, F. Scarpa."Hybrid poly meric composites reinforced with sisal fibres and silica microparticles". Composites Part B: Engineering, Available online 9 January 2012, ISSN 1359-8368, 10.1016/j.compositesb.2012.01.026.

[15] ASTM Standard D792, 2008. "Test Methods for Density and Specific Gravity (Relative Density) of Plastics by Displacement," ASTM International, West Conshohocken, PA, 2008, DOI: 10.1520/D0792-08, www.astm.org.

[16] ASTM Standard D570, 1998 (2010). "Test Method for Water Absorption of Plastics," ASTM International, West Conshohocken, PA, 2010, DOI: 10.1520/D0570-98R10E01, www.astm.org.

[17] ASTM Standard D790, 2010. "Test Methods for flexural Properties of Unreinforced and Reinforced Plastics and Electrical Insulating Materials," ASTM International, West Conshohocken, PA, 2010, DOI: 10.1520/D0790-10, www.astm.org.

[18] D. C. Montgomerry, G. C. Runger. "Estatística aplicada e probabilidade para en genheiros." 4. ed. Rio de Janeiro: LTC, pp 208-217. 2009. 